\title{
Cellulose factories: advancing bioenergy production from forest trees
}

\author{
Eshchar Mizrachi ${ }^{1}$, Shawn D. Mansfield ${ }^{2}$ and Alexander A. Myburg ${ }^{1}$ \\ 1- Department of Genetics, Forestry and Agricultural Biotechnology Institute (FABI), University of Pretoria, Pretoria, 0002, \\ South Africa \\ 2 - Department of Wood Science, University of British Columbia, Vancouver, BC, Canada V6T 1Z4
}

Author for correspondence:

Prof. A. A. Myburg

Department of Genetics

University of Pretoria

Pretoria, South Africa

Tel: +27(0)12 4204945

Fax: $+27(0) 123625327$

Email: zander.myburg@fabi.up.ac.za

\section{Word count}

Summary: 200

Body: 3580

Conclusion: 245

Tables: none

Figures: 4 (Figure 1 and Figure 2 in colour) 


\section{Summary}

Fast-growing, short-rotation forest trees such as Populus and Eucalyptus produce large amounts of cellulose-rich biomass that could be utilized for bioenergy and biopolymer production. Major obstacles need to be overcome prior to deploying these genera as energy crops, including the effective removal of lignin and subsequent liberation of carbohydrate constituents from wood cell walls. However, significant opportunities exist to both select for and engineer the structure and interaction of cell wall biopolymers, which could afford a means to improve processing and product development. The molecular underpinnings and regulation of cell wall carbohydrate biosynthesis are rapidly being elucidated, and are providing tools to strategically develop and guide the targeted modification required to adapt forest trees for the emerging bioeconomy. Much insight has already been gained from the perturbation of individual genes and pathways, but it is not known to what extent natural variation in the sequence and expression of these same genes underlie the inherent variation in wood properties of field-grown trees. Integration of data from next-generation genomic technologies applied in natural and experimental populations will enable a systems genetics approach to study cell wall carbohydrate production in trees, and should advance the development of future woody bioenergy and biopolymer crops.

Keywords: cellulose, hemicellulose, sucrose, bioenergy, Eucalyptus, Populus, systems genetics 


\section{Introduction}

With the growing need for alternative sources of energy and raw materials, fast-growing plantation tree species such as Populus and Eucalyptus are important candidates for renewable sources of lignocellulosic biomass (for recent reviews on the feasability of bioenergy production from wood biomass refer to Carroll \& Somerville, 2009; Hinchee et al., 2009; Mansfield, 2009; Richard, 2010; Somerville et al., 2010; Séguin, 2011). These two genera, broadly representing the Northern and Southern hemisphere, respectively, produce large amounts of woody biomass $\left(>50 \mathrm{~m}^{3} /\right.$ ha/year for eucalypts in highly productive areas such as Brazil) in relatively short rotation times, and in general, do not infringe on land dedicated to food crop production. In addition, contrary to agriculture-derived biomass, treederived lignocellulosics can be harvested year-round to ensure a stable, predictable and constant supply of raw material for bioenergy or biofuel production. Establishment costs and carbon footprints of multiyear forest plantations are also lower than that of annually planted crops, especially for coppicing eucalypt species, which can be grown on marginal lands (Hinchee et al., 2009). Well-established industrial breeding programmes already exploit the substantial inherent genetic variation available in these genera, which can be (and has been) expanded with interspecific hybridization, and ultimately captured in clonal plantations (Grattapaglia et al., 2009). The processing of wood fibre, and especially cellulose, from woody biomass has been improved and optimized for decades providing a technology base from which to develop processing plants for biofuels and biomaterials. One major consideration that is often overlooked when forecasting bioenergy feedstocks is that this bioenergy end-use will have to compete with the high value products derived from chemical cellulose and its derivatives (Figure 1), and the desired traits for many bioenergy applications are common to those desired for chemical cellulose production. Thus, the 
objective of improving feedstock characteristics in trees is complementary to current tree breeding programs directed at traditional forest-reliant industries.

Cellulose-rich biomass derived from fast-growing tree species offers many advantages over agricultural feedstocks for bioenergy production, but the removal of lignin to facilitate the effective and efficient extraction of cell wall carbohydrates remains one of the primary hurdles (Studer et al., 2011). To efficiently deconstruct lignocellulosic biomass, a detailed understanding of how wood cell walls are synthesized, deposited and modified in planta is required (Mansfield, 2009). Recent research has mainly focused on the modification of lignin, the most abundant natural biopolymer after cellulose (Vanholme et al., 2008), but much remains to be learned about the possibilities for modifying and regulating the synthesis of cellulose, ultimately impacting the overall chemistry and ultrastructure of wood cell walls. While major advances have been made in understanding the biosynthesis of cellulose itself (Joshi \& Mansfield, 2007), the underlying cellular and biochemical processes that influence cellulose properties in wood cell walls have not yet been fully dissected.

Most of our current knowledge of cellulose biosynthesis stems from studies in model herbaceous plants such as Arabidopsis thaliana and to some extent, extension of this knowledge to woody plant genera such as Populus (Joshi et al., 2011). The poplar genome sequence (Tuskan et al., 2006) has been available for five years, and as of 2011, the genome sequence of Eucalyptus grandis (Myburg et al., in preparation) is also publically available (http://www.phytozome.net). These two landmark achievements open up new avenues for exploiting genetic variation in forest trees, and strategically improving the physicochemical properties of woody biomass. The availability of a genome sequence is particularly important for Eucalyptus, the most widely grown hardwood crop in the world ( $\sim 20$ million ha). With advances in next generation sequencing technologies, comparative genomics can now be applied to rapidly adopt the information learned from herbaceous models and other woody 
plants such as poplars to accelerate Eucalyptus improvement. However, with so many candidate genes known to influence xylogenesis, how does one prioritize targets when considering forest trees as bioenergy crops? How can one expand the fundamental understanding of the biology and biosynthesis of cellulose and its interaction with other wood cell wall polymers?

Here, we provide a current summary of the general understanding of the molecular biology of cellulose production in plants and discuss how the integration of emerging functional genomics technologies with the wealth of fundamental information on wood properties in tree breeding programmes, could be used to accelerate the improvement of cellulose and bioenergy potential in trees.

\section{An integrated view of proteins involved in cellulose biosynthesis and deposition}

Historically, the biosynthesis of cellulose has focussed on the plasma membrane-located cellulose synthase (CESA) proteins that constitute the active synthesising complex (CSC; cellulose synthase complex), which is ultimately responsible for producing the polymeric glucan chains that coalesce to form cellulose microfibrils in primary and secondary cell walls of plants (Delmer, 1999; Doblin et al., 2002; Saxena \& Brown Jr, 2005; Somerville, 2006; Bessueille \& Bulone, 2008; Taylor, 2008; Guerriero et al., 2010). Building on these solid foundations, our current understanding requires an integrated view that incorporates a diverse set of proteins and regulatory mechanisms to fully understand this intricate biological process. Such a view should take into consideration the variety of cellular processes and metabolic fluxes that could, and do, influence the synthesis, deposition and physical properties of cellulose in the two distinctly different cell walls. This holistic view should also 
include the inherent and tightly regulated interactions of cellulose with other cell wall biopolymers, such as lignin and hemicellulose. For example, the biosynthesis and deposition of xylan, a major constituent of the dicot secondary cell wall (Scheller \& Ulvskov, 2010) is closely coordinated with the deposition of cellulose (Hertzberg et al., 2001; Schrader et al., 2004). Thus, to advance our fundamental understanding, and further the biotechnological objectives of improving cellulose-rich resources, research areas to be explored should focus on the transcriptional regulation of xylem forming genes; as well as post-translational modification, protein folding and protein-complex assembly; substrate (metabolite) production, transport and availability; the transport of proteins and/or polysaccharides between organelles and to the plasma membrane; and, signalling and feedback between the extracellular environment and the cytoplasm, organelles and nucleus.

Using Arabidopsis as the primary model, the current architecture of proteins and cellular processes thought to be involved in, or influence the biosynthesis and deposition of cellulose and xylan is illustrated in Figure 2. At the level of transcriptional regulation, several transcription factors have been shown to directly regulate secondary cell wall CesA genes in Arabidopsis (Zhong et al., 2008; Yamaguchi et al., 2010; Xie et al., 2011). Three of these SND2, SND3 and MYB103 - appear to specifically regulate secondary cell wall CesA genes but not xylan or lignin genes (Zhong et al., 2008). These transcription factors are part of a complex transcriptional network regulating various aspects of xylogenesis, the extent of which is still being resolved in Arabidopsis (Kubo et al., 2005; Zhong et al., 2006; Demura \& Fukuda, 2007; Zhong et al., 2007; Zhong et al., 2008), as well as more recently in Populus (McCarthy et al., 2010; Zhong et al., 2010; Zhong \& Ye, 2010; Zhong et al., 2011).

CESA proteins are synthesized and assembled into complexes in the ER (Rudolph, 1987) and, with the help of chaperones, packaged and delivered to the Golgi (Haigler \& Brown Jr, 1986). The Golgi (Figure 2) is also the site for xylan biosynthesis (Bolwell \& Northcote, 
1983), which can be divided, simplistically, into primer synthesis (PARVUS), chain elongation (IRX9, 10 and 14) and side chain modifications by IRX7, IRX8, PGSIP1, DUF579- and/or DUF231-containing proteins (Brown et al., 2007; Lee et al., 2007; York \& O'Neill, 2008; Brown et al., 2009; Wu et al., 2009; Wu et al., 2010; Brown et al., 2011; Jensen et al., 2011). Once the cellulose synthase complexes (CSCs) are assembled, they are transported from the Golgi to the plasma membrane via the trans-Golgi network in specialized microtubule-associated compartments (MASCs; Crowell et al., 2009) that interact with actin through MYOSIN (Wightman \& Turner, 2008; Szymanski, 2009). At the plasma membrane, MASCs interact with cortical microtubules, possibly but not conclusively via KINESIN, and bud vesicles containing CSCs that fuse with and become embedded in the plasma membrane (Giddings Jr et al., 1980; Szymanski, 2009; Crowell et al., 2010).

On the cytoplasmic face (Figure 2), the CSCs associate with cortical microtubules, putatively through kinesin-like proteins such as FRA1 (Zhong et al., 2002), CSI1 (Gu et al., 2010), and other microtubule associated proteins (MAPs). It is therefore apparent that cortical microtubule organization is extremely important in regulating and depositing cellulose, and the structure and orientation of said cortical microtubules is influenced by a variety of factors. From the assembly of $\alpha$ - and $\beta$-TUB at microtubule assembly sites containing $\gamma$-TUB and Gamma-complex proteins (Pastuglia \& Bouchez, 2007; Cai, 2010), growth and modification of the microtubules is influenced by strong association with actin via $\mathrm{KCH}$ and MAP190 (Cai, 2010), association with other microtubules via MAP65-1, MAP 200, TBMP 200 and/or MOR1 (Cai, 2010), and association with the plasma membrane via proteins such as EB1 (Morrison, 2007), P-161 (Cai et al., 2005), ATK5 (Ambrose \& Cyr, 2007; Pastuglia \& Bouchez, 2007), SPR1 (Nakajima et al., 2004; Sedbrook et al., 2004; Nakajima et al., 2006), CLIPs and CLASPs (Galjart, 2005; Ambrose \& Wasteneys, 2008), and PHOSPHOLIPASED (Cai, 2010). Microtubule length and organization is also modified by KATANIN (McNally 
\& Vale, 1993; Burk et al., 2001; Stoppin-Mellet et al., 2006; Sharma et al., 2007), and therefore can impact the quality and quantity of cellulose. Transamination, tyrosylation or acetylation of microtubules can influence the binding of KINESIN proteins, while glutamination or glycylation of microtubules has been shown to influence KATANIN activity (Cai, 2010). These, and other as yet unidentified proteins, could all potentially have direct or indirect effects on cellulose deposition, via their influence on cortical microtubule dynamics.

Movement of the CSC along the membrane is believed to be driven by the force of cellulose microfibril synthesis itself against the cell wall matrix (Diotallevi \& Mulder, 2007), and is guided by the cortical microtubules (Paredez et al., 2006), with membrane-associated sucrose synthase (SUSY) providing UDP-glucose as substrate for the CSC (Figure 2). Towards the cell wall side, KORRIGAN (KOR - Lane et al., 2001) and possibly other glycosyl hydrolases edit elongating cellulose chains as they are synthesized, while COBRA/COBL and possibly other GPI-anchored proteins, as well as the fasciclin-like arabinogalactan (FLA) proteins and/or other arabinogalactan proteins (AGPs) are thought to interact with cellulose as it is deposited, and concurrently relay signals back to the cytoplasm to regulate its synthesis (Zhang et al., 2003; Seifert \& Roberts, 2007; MacMillan et al., 2010).

The mediation of cell wall feedback signalling is carried out by a number of pathways, and recently the Rop/Rac GTPases (Figure 2), which are regulated by RIC and Rop-GEF, have been highlighted as playing an important role in cell wall signalling, along with IQD and CTL proteins, and wall-associated kinases (WAKs) such as LRR-receptor kinases (Oikawa et al., 2010). The LRR-receptor kinases include, amongst others, THESEUS (Hématy et al., 2007) and KOBITO/ELD1 (Pagant et al., 2002; Lertpiriyapong \& Sung, 2003) both of which have been shown to impact cell wall properties. In the secondary cell wall, laccases (LAC) and other peroxidases oxidize monolignols, leading to the random coupling of lignin monomers and resulting in the synthesis of the macromolecule lignin polymer (Boerjan et al., 
2003; Ralph et al., 2004; Mattinen et al., 2008), while other as yet unidentified glycosyl hydrolases $(\mathrm{GH})$ and carbohydrate binding module (CBM)-containing proteins appear to be involved in mediating cellulose-cellulose, cellulose-xylan, xylan-xylan or xylan-lignin interactions as the different biopolymers are synthesized, deposited and arranged.

In addition to the cellular processes and specific proteins involved in cellulose deposition itself, it is important to consider the metabolic flux and channelling to the various biochemical pathways that lead to the synthesis of cellulose and xylan. For example, a key metabolite is uridine diphosphate- (UDP)-glucose, which is the immediate pre-cursor for cellulose biosynthesis by CESA proteins. In addition, UDP-glucose can be readily converted to UDP-xylose for xylan biosynthesis (Figure 3). UDP-glucose is produced directly via the hydrolysis of sucrose by sucrose SUSY or indirectly by invertase (Barratt et al., 2009; Kleczkowski et al., 2010), which cleaves sucrose to monomeric glucose and fructose. Monomeric glucose is then converted to UDP-glucose via phosphorylation of the 6 ' position (HEXOKINASE/GLUCOKINASE), followed by the substitution of the phosphate to the 1' position (PHOSPHOGLUCOMUTASE) and the subsequent substitution of the phosphate group with UDP by UTP-glucose-1-phosphate uridylyltransferase (UGP). UDP-glucose can be directly employed by CESA proteins for cellulose biosynthesis, or converted to UDPxylose via conversion to UDP-D-glucuronate by UDP-glucose 6-dehydrogenase (UGHD), followed by the removal of $\mathrm{CO}_{2}$ by uridine-diphosphoglucuronate decarboxylase (UXS). UDP-xylose is then utilized as the backbone for xylan biosynthesis, with the addition of glucuronic acid (GlcA) and acetyl groups to the backbone or side chains to form heteroxylan.

Studies have shown that alteration in the metabolic flux of UDP-glucose can indeed affect the relative abundance and structure of cell wall polysaccharides. For example, upregulation of $S U S Y$ in poplar trees resulted in an increase in cell wall thickness of fibres, and production of more cellulose that displayed enhanced crystallinity (Coleman et al., 2009). The combination 
of $S U S Y$ and $U G P$ overexpression in tobacco also resulted in a synergistic increase in plant height and biomass (Coleman et al., 2006). It should be noted that the overall phenotypic effect of increased SUSY or UGP levels would be dependent on source and sink sugars and other metabolites (Haigler et al., 2001; Coleman et al., 2009; Meng et al., 2009), which will vary in different plant species, and under an array of physiological conditions. These studies demonstrate that changes in metabolite levels, through intra and inter-cellular transport or enzymatic activity, could greatly influence the resulting abundance and/or structure of cell wall polysaccharides.

\section{Towards systems genetics of cellulose production in trees}

The scale of cellulose biosynthesis and biomass production in fast-growing plantation trees is vastly different from that in herbaceous models. There is an emphasis on large-scale cambial cell differentiation, cell elongation, secondary cell wall deposition and programmed cell death. The tremendous strength of the sink tissue means that the tree as a system must prioritize channelling carbon flow towards the synthesis of xylem biopolymers. Therefore, information cannot always be directly extended from herbaceous models to trees - good examples of this are the different outcomes that resulted from overexpressing SUSY in tobacco plants (Coleman et al., 2006) as opposed to poplar (Coleman et al., 2009), or the fact that for Arabidopsis, INVERTASE is necessary and sufficient for normal growth whereas direct UDP-glucose production through SUSY is not (Barratt et al., 2009). Recent findings also suggest that the transcriptional network regulating cell wall biopolymer synthesis in woody plants may be more complex and comprise novel transcription factors not previously linked to secondary cell wall formation in Arabidopsis (Zhong et al., 2011). This implies the need to independently study the functions of secondary cell wall related genes in trees. Some practical considerations are that very few commercial species and clonal genotypes have 
optimized transformation protocols; mature wood properties take several years to acquire; and wood properties are complex traits affected by large numbers of genes. Rigorous greenhouse studies and field trials are required for each candidate, and these carry significant economical, ecological and regulatory burdens (for recent reviews on this issue see Ahuja, 2011; Harfouche et al., 2011; Strauss et al., 2009). What is required is an approach that would prioritize genes or pathways that underlie variation in wood properties in mature, field grown trees.

At our disposal is a rich history of tree breeding, resulting in large, structured populations, and large amounts of genetic diversity in these populations (Sederoff et al., 2009; Neale \& Kremer, 2011). These resources have been exploited through the application of molecular marker technologies and forward genetics approaches in multiple forest tree pedigrees where high linkage disequilibrium (LD) has allowed the efficient identification of quantitative trait loci (QTL -Grattapaglia \& Kirst, 2008), as well as in large association populations where low LD has allowed the association of single genes with wood properties (Groover, 2007; Neale \& Ingvarsson, 2008). Single gene associations detected in Eucalyptus and Populus (Thumma et al., 2005; Thumma et al., 2009; Wegrzyn et al., 2010) have not always been intuitive - for example the association between a lignin gene (cinnamoyl CoA reductase, $C C R$ ) and a physical cellulose property (microfibril angle) in Eucalyptus (Thumma et al., 2005). This illustrates that our understanding of the causal relationship of genes and complex traits is still incomplete.

Phenotypic variation in tree breeding populations is influenced by a variety of intrinsic (and measurable) biological processes, mainly those of transcriptional and translational regulation of various biochemical pathways (Du \& Groover, 2010), as well as the flux of metabolic intermediates in these pathways (Mansfield, 2009). In addition, these biological processes are strongly impacted by environmental cues and seasonal variation over the lifetime of these 
long-lived organisms (Groover, 2007). A more holistic research approach encompassing genetic, biochemical and environmental variation must therefore be adopted to understand and improve wood property traits in trees.

Systems genetics (Figure 4) connects the intermediate components of a complex phenotype (e.g. transcript, protein and metabolite levels) in related individuals to measurable phenotypic traits such as wood properties or bioenergy potential, in the context of the underlying genetic variation in populations (MacKay et al., 2009; Nadeau \& Dudley, 2011). An extension of genetical genomics (Jansen \& Nap, 2001), systems genetics is a network approach that explores the interconnectedness of the component levels of biological variation. It has been successfully applied in model organisms such as Drosophila (Ayroles et al., 2009; Morozova et al., 2009; Jumbo-Lucioni et al., 2010) and mouse (Farber et al., 2011). It has also been applied in humans (Plaisier et al., 2009; Romanoski et al., 2010), and importantly in animal breeding (Kadarmideen et al., 2006; Kadarmideen \& Janss, 2007; Kadarmideen \& Janss, 2009), which has many similarities to plant breeding. The power of systems genetics is that it reveals emergent properties of the system, providing insight into novel gene-gene, gene-trait and trait-trait relationships that would not be detected at the level of the individual. This often allows reconstruction of complex directional gene regulatory networks and metabolic pathways (Kadarmideen et al., 2006; Keurentjes et al., 2007), adding insight to previously identified single gene associations and the molecular basis of QTLs. Systems genetics could also explain the biology underlying complex phenomena such as $\mathrm{G} \times \mathrm{E}$ interactions, epigenetic control, biotic and abiotic interactions and hybrid vigour (heterosis), which are key themes to be addressed in tree improvement in the near future.

Tree breeding programmes already make use of structured pedigrees and populations replicated across environments, and therefore present an ideal starting place for systems 
genetics. Variation in transcriptomes have already been studied at the population level in Eucalyptus (Kirst et al., 2005; Grattapaglia \& Kirst, 2008) and Populus (Drost et al., 2010). Transcriptome, proteome and metabolome profiling at the population level will allow integrated modelling of biomass production in trees. Systems genetics is complementary to fundamental biological investigations performed in model organisms and will also complement association genetics approaches and genomic selection strategies that are being implemented in forest tree breeding programs (Grattapaglia \& Resende, 2011). Moreover, systems genetics will allow the identification and prioritization of candidate genes for functional genetic testing in greenhouse and field trials of forest trees.

\section{Conclusion}

Understanding how cellulose is deposited during xylogenesis in wood fibre cells has important implications for our ability to manipulate and select for bioenergy traits in trees. We also need to understand the complex genetic relationships and biochemical interactions that underlie wood property variation in tree populations. Application of next-generation DNA and RNA sequencing (Mizrachi et al., 2010), and the adoption of high throughput proteomics and metabolomics technologies in trees (Abril et al., 2011; Dauwe et al., 2011; Robinson and Mansfield, 2011) will allow integrated approaches to study complex relationships of genes, metabolites and wood (bio)chemistry traits at the population level. A systems genetics approach, which also includes the measurement of bioenergy potential, is a viable and increasingly cost effective method to dissect complex phenotypes in trees and will complement genomic selection efforts. It will also permit one to address the fundamental question whether the same genes linked to cell wall biosynthesis by functional genetic studies in individual genotypes are also influencing cell wall properties in natural or experimental populations. Additionally, the diversity of applications of next-generation DNA sequencing 
will enable investigation of other types of regulation such as allele-specific expression, splice site variation, gene regulation by endogenous small RNAs, or epigenetic modification that may impact the bioenergy potential of forest trees. Finally, the completion of additional tree genome sequences will permit comparative genomics approaches to dissect vital biosynthetic pathways important to industrial trait development, which should form the foundations of the emerging bio-based economy.

\section{References}

Abril N, Gion JM, Kerner R, Müller-Starck G, Cerrillo RMN, Plomion C, Renaut J, Valledor L, Jorrin-Novo JV. 2011. Proteomics research on forest trees, the most recalcitrant and orphan plant species. Phytochemistry 72(10): 1219-1242.

Ahuja MR. 2011. Fate of transgenes in the forest tree genome. Tree Genetics and Genomes 7(2): 221230.

Ambrose CJ, Wasteneys GO. 2008. CLASP modulates microtubule-cortex interaction during selforganization of acentrosomal microtubules. Molecular Biology of the Cell 19(11): 4730-4737.

Ambrose JC, Cyr R. 2007. The kinesin ATK5 functions in early spindle assembly in Arabidopsis. Plant Cell 19(1): 226-236.

Ayroles JF, Carbone MA, Stone EA, Jordan KW, Lyman RF, Magwire MM, Rollmann SM, Duncan LH, Lawrence F, Anholt RRH, Mackay TFC. 2009. Systems genetics of complex traits in Drosophila melanogaster. Nature Genetics 41(3): 299-307.

Barratt DHP, Derbyshire P, Findlay K, Pike M, Wellner N, Lunn J, Feil R, Simpson C, Maule AJ, Smith AM. 2009. Normal growth of Arabidopsis requires cytosolic invertase but not sucrose synthase. Proceedings of the National Academy of Sciences of the United States of America 106(31): 13124-13129.

Bessueille L, Bulone V. 2008. A survey of cellulose biosynthesis in higher plants. Plant Biotechnology 25(3): 315-322.

Boerjan W, Ralph J, Baucher M 2003. Lignin Biosynthesis. In. Annual Review of Plant Biology. 519546.

Bolwell GP, Northcote DH. 1983. Arabinan synthase and xylan synthase activities of Phaseolus vulgaris. Subcellular localization and possible mechanism of action. Biochemical Journal 210(2): 497-507.

Brown D, Wightman R, Zhang Z, Gomez LD, Atanassov I, Bukowski JP, Tryfona T, McQueenMason SJ, Dupree P, Turner S. 2011. Arabidopsis genes IRREGULAR XYLEM (IRX15) and $I R X 15 L$ encode DUF579-containing proteins that are essential for normal xylan deposition in the secondary cell wall. Plant Journal 66(3): 401-413.

Brown DM, Goubet F, Wong VW, Goodacre R, Stephens E, Dupree P, Turner SR. 2007. Comparison of five xylan synthesis mutants reveals new insight into the mechanisms of xylan synthesis. Plant Journal 52(6): 1154-1168.

Brown DM, Zhang Z, Stephens E, Dupree P, Turner SR. 2009. Characterization of IRX10 and IRX10-like reveals an essential role in glucuronoxylan biosynthesis in Arabidopsis. Plant Journal 57(4): 732-746.

Burk DH, Liu B, Zhong R, Morrison WH, Ye ZH. 2001. A katanin-like protein regulates normal cell wall biosynthesis and cell elongation. Plant Cell 13(4): 807-827. 
Cai G. 2010. Assembly and disassembly of plant microtubules: Tubulin modifications and binding to MAPs. Journal of Experimental Botany 61(3): 623-626.

Cai G, Ovidi E, Romagnoli S, Vantard M, Cresti M, Tiezzi A. 2005. Identification and characterization of plasma membrane proteins that bind to microtubules in pollen tubes and generative cells of tobacco. Plant and Cell Physiology 46(4): 563-578.

Carroll A, Somerville C. 2009. Cellulosic biofuels. Annual Review of Plant Biology 60: 165-182.

Coleman HD, Ellis DD, Gilbert M, Mansfield SD. 2006. Up-regulation of sucrose synthase and UDPglucose pyrophosphorylase impacts plant growth and metabolism. Plant Biotechnology Journal 4(1): 87-101.

Coleman HD, Yan J, Mansfield SD. 2009. Sucrose synthase affects carbon partitioning to increase cellulose production and altered cell wall ultrastructure. Proceedings of the National Academy of Sciences of the United States of America 106(31): 13118-13123.

Crowell EF, Bischoff V, Desprez T, Rolland A, Stierhof YD, Schumacher K, Gonneau M, Höfte H, Vernhettes S. 2009. Pausing of golgi bodies on microtubules regulates secretion of cellulose synthase complexes in Arabidopsis. Plant Cell 21(4): 1141-1154.

Crowell EF, Gonneau M, Stierhof YD, Höfte H, Vernhettes S. 2010. Regulated trafficking of cellulose synthases. Current Opinion in Plant Biology 13(6): 700-705.

Dauwe R, Robinson A, Mansfield SD. 2011. Recent advances in proteomics and metabolomics in gymnosperms. In C. Plomion, J. Bousquet and K. Chittaranjan (Eds.). Genetics, Genomics and Breeding of Conifers. CRC Press, Science Publishers, Inc., New Hampshire; Edenbridge Ltd., British Isles. Pp. 358-388.

Delmer DP. 1999. CELLULOSE BIOSYNTHESIS: Exciting times for a difficult field of study. Annu Rev Plant Physiol Plant Mol Biol 50: 245-276.

Demura T, Fukuda H. 2007. Transcriptional regulation in wood formation. Trends in Plant Science 12(2): 64-70.

Diotallevi F, Mulder B. 2007. The cellulose synthase complex: A polymerization driven supramolecular motor. Biophysical Journal 92(8): 2666-2673.

Doblin MS, Kurek I, Jacob-Wilk D, Delmer DP. 2002. Cellulose biosynthesis in plants: from genes to rosettes. Plant Cell Physiol 43(12): 1407-1420.

Drost DR, Benedict CI, Berg A, Novaes E, Novaes CRDB, Yu Q, Dervinis C, Maia JM, Yap J, Miles B, Kirst M. 2010. Diversification in the genetic architecture of gene expression and transcriptional networks in organ differentiation of Populus. Proceedings of the National Academy of Sciences of the United States of America 107(18): 8492-8497.

Du J, Groover A. 2010. Transcriptional regulation of secondary growth and wood formation. Journal of Integrative Plant Biology 52(1): 17-27.

Farber CR, Bennett BJ, Orozco L, Zou W, Lira A, Kostem E, Kang HM, Furlotte N, Berberyan A, Ghazalpour A, Suwanwela J, Drake TA, Eskin E, Wang QT, Teitelbaum SL, Lusis AJ. 2011. Mouse genome-wide association and systems genetics identify Asx12 as a regulator of bone mineral density and osteoclastogenesis. PLoS Genetics 7(4).

Galjart N. 2005. CLIPs and CLASPs and cellular dynamics. Nature Reviews Molecular Cell Biology 6(6): 487-498.

Giddings Jr TH, Brower DL, Staehelin LA. 1980. Visualization of particle complexes in the plasma membrane of Micrasterias denticulata associated with the formation of cellulose fibrils in primary and secondary cell walls. Journal of Cell Biology 84(2): 327-339.

Grattapaglia D, Kirst M. 2008. Eucalyptus applied genomics: From gene sequences to breeding tools. New Phytologist 179(4): 911-929.

Grattapaglia D, Plomion C, Kirst M, Sederoff RR. 2009. Genomics of growth traits in forest trees. Current Opinion in Plant Biology 12(2): 148-156.

Grattapaglia D, Resende MDV. 2011. Genomic selection in forest tree breeding. Tree Genetics and Genomes 7(2): 241-255.

Groover AT. 2007. Will genomics guide a greener forest biotech? Trends in Plant Science 12(6): 234238.

Gu Y, Kaplinsky N, Bringmann M, Cobb A, Carroll A, Sampathkumar A, Baskin TI, Persson S, Somerville CR. 2010. Identification of a cellulose synthase-associated protein required for 
cellulose biosynthesis. Proceedings of the National Academy of Sciences of the United States of America 107(29): 12866-12871.

Guerriero G, Fugelstad J, Bulone V. 2010. What do we really know about cellulose biosynthesis in higher plants? Journal of Integrative Plant Biology 52(2): 161-175.

Haigler CH, Brown Jr RM. 1986. Transport of rosettes from the golgi apparatus to the plasma membrane in isolated mesophyll cells of Zinnia elegans during differentiation to tracheary elements in suspension culture. Protoplasma 134(2-3): 111-120.

Haigler CH, Ivanova-Datcheva M, Hogan PS, Salnikov VV, Hwang S, Martin K, Delmer DP. 2001. Carbon partitioning to cellulose synthesis. Plant Molecular Biology 47(1-2): 29-51.

Harfouche A, Meilan R, Altmane A. 2011. Tree genetic engineering and applications to sustainable forestry and biomass production. Trends in Biotechnology 29(1): 9-17.

Hématy K, Sado PE, Van Tuinen A, Rochange S, Desnos T, Balzergue S, Pelletier S, Renou JP, Höfte H. 2007. A receptor-like kinase mediates the response of Arabidopsis cells to the inhibition of cellulose synthesis. Current Biology 17(11): 922-931.

Hertzberg M, Aspeborg H, Schrader J, Andersson A, Erlandsson R, Blomqvist K, Bhalerao R, Uhlén M, Teeri TT, Lundeberg J, Sundberg B, Nilsson P, Sandberg G. 2001. A transcriptional roadmap to wood formation. Proceedings of the National Academy of Sciences of the United States of America 98(25): 14732-14737.

Hinchee M, Rottmann W, Mullinax L, Zhang C, Chang S, Cunningham M, Pearson L, Nehra N. 2009. Short-rotation woody crops for bioenergy and biofuels applications. In Vitro Cellular and Developmental Biology - Plant 45(6): 619-629.

Jansen RC, Nap JP. 2001. Genetical genomics: The added value from segregation. Trends in Genetics 17(7): 388-391.

Jensen JK, Kim H, Cocuron JC, Orler R, Ralph J, Wilkerson CG. 2011. The DUF579 domain containing proteins IRX15 and IRX15-L affect xylan synthesis in Arabidopsis. Plant Journal 66(3): 387-400.

Joshi CP, Mansfield SD. 2007. The cellulose paradox - simple molecule, complex biosynthesis. Current Opinion in Plant Biology 10(3): 220-226.

Joshi CP, Thammannagowda S, Fujino T, Gou JQ, Avci U, Haigler CH, McDonnell LM, Mansfield SD, Mengesha B, Carpita NC, Harris D, Debolt S, Peter GF. 2011. Perturbation of wood cellulose synthesis causes pleiotropic effects in transgenic aspen. Molecular Plant 4(2): 331345 .

Jumbo-Lucioni P, Ayroles JF, Chambers MM, Jordan KW, Leips J, Mackay TFC, De Luca M. 2010. Systems genetics analysis of body weight and energy metabolism traits in Drosophila melanogaster. BMC Genomics 11(1).

Kadarmideen HN, Janss LLG. 2007. Population and systems genetics analyses of cortisol in pigs divergently selected for stress. Physiological Genomics 29(1): 57-65.

Kadarmideen HN, Janss LLG. 2009. Population and systems genetics analyses of cortisol in pigs divergently selected for stress. Physiological Genomics 37(3): 303.

Kadarmideen HN, Von Rohr P, Janss LLG. 2006. From genetical genomics to systems genetics: Potential applications in quantitative genomics and animal breeding. Mammalian Genome 17(6): 548-564.

Keurentjes JJB, Fu J, Terpstra IR, Garcia JM, Van Den Ackerveken G, Snoek LB, Peeters AJM, Vreugdenhil D, Koornneef M, Jansen RC. 2007. Regulatory network construction in Arabidopsis by using genome-wide gene expression quantitative trait loci. Proceedings of the National Academy of Sciences of the United States of America 104(5): 1708-1713.

Kirst M, Basten CJ, Myburg AA, Zeng ZB, Sederoff RR. 2005. Genetic architecture of transcriptlevel variation in differentiating xylem of a Eucalyptus hybrid. Genetics 169(4): 2295-2303.

Kleczkowski LA, Kunz S, Wilczynska M. 2010. Mechanisms of UDP-glucose synthesis in plants. Critical Reviews in Plant Sciences 29(4): 191-203.

Kubo M, Udagawa M, Nishikubo N, Horiguchi G, Yamaguchi M, Ito J, Mimura T, Fukuda H, Demura T. 2005. Transcription switches for protoxylem and metaxylem vessel formation. Genes and Development 19(16): 1855-1860.

Lane DR, Wiedemeier A, Peng L, Höfte H, Vernhettes S, Desprez T, Hocart CH, Birch RJ, Baskin TI, Burn JE, Arioli T, Betzner AS, Williamson RE. 2001. Temperature-sensitive alleles of $r s w 2$ 
link the KORRIGAN endo-1,4- $\beta$-glucanase to cellulose synthesis and cytokinesis in Arabidopsis. Plant Physiology 126(1): 278-288.

Lee C, Zhong R, Richardson EA, Himmelsbach DS, McPhail BT, Ye ZH. 2007. The PARVUS gene is expressed in cells undergoing secondary wall thickening and is essential for glucuronoxylan biosynthesis. Plant and Cell Physiology 48(12): 1659-1672.

Lertpiriyapong K, Sung ZR. 2003. The elongation defective1 mutant of Arabidopsis is impaired in the gene encoding a serine-rich secreted protein. Plant Molecular Biology 53(4): 581-595.

MacKay TFC, Stone EA, Ayroles JF. 2009. The genetics of quantitative traits: Challenges and prospects. Nature Reviews Genetics 10(8): 565-577.

MacMillan CP, Mansfield SD, Stachurski ZH, Evans R, Southerton SG. 2010. Fasciclin-like arabinogalactan proteins: Specialization for stem biomechanics and cell wall architecture in Arabidopsis and Eucalyptus. Plant Journal 62(4): 689-703.

Mansfield SD. 2009. Solutions for dissolution-engineering cell walls for deconstruction. Current Opinion in Biotechnology 20(3): 286-294.

Mattinen ML, Suortti T, Gosselink R, Argyropoulos DS, Evtuguin D, Suurnäkki A, De Jong E, Tamminen T. 2008. Polymerization of different lignins by laccase. BioResources 3(2): 549565.

McCarthy RL, Zhong R, Fowler S, Lyskowski D, Piyasena H, Carleton K, Spicer C, Ye ZH. 2010. The poplar MYB transcription factors, PtrMYB3 and PtrMYB20, are involved in the regulation of secondary wall biosynthesis. Plant and Cell Physiology 51(6): 1084-1090.

McNally FJ, Vale RD. 1993. Identification of katanin, an ATPase that severs and disassembles stable microtubules. Cell 75(3): 419-429.

Meng M, Geisler M, Johansson H, Harholt J, Scheller HV, Mellerowicz EJ, Kleczkowski LA. 2009. UDP-glucose pyrophosphorylase is not rate limiting, but is essential in Arabidopsis. Plant and Cell Physiology 50(5): 998-1011.

Mizrachi E, Hefer CA, Ranik M, Joubert F, Myburg AA. 2010. De novo assembled expressed gene catalog of a fast-growing Eucalyptus tree produced by Illumina mRNA-Seq. BMC Genomics $11(1)$.

Morozova TV, Ayroles JF, Jordan KW, Duncan LH, Carbone MA, Lyman RF, Stone EA, Govindaraju DR, Ellison RC, Mackay TFC, Anholt RRH. 2009. Alcohol sensitivity in Drosophila: Translational potential of systems genetics. Genetics 183(2): 733-745.

Morrison EE. 2007. Action and interactions at microtubule ends. Cellular and Molecular Life Sciences 64(3): 307-317.

Nadeau JH, Dudley AM. 2011. Systems genetics. Science 331(6020): 1015-1016.

Nakajima K, Furutani I, Tachimoto H, Matsubara H, Hashimoto T. 2004. Spiral1 encodes a plantspecific microtubule-localized protein required for directional control of rapidly expanding arabidopsis cells. Plant Cell 16(5): 1178-1190.

Nakajima K, Kawamura T, Hashimoto T. 2006. Role of the SPIRAL1 gene family in anisotropic growth of Arabidopsis thaliana. Plant and Cell Physiology 47(4): 513-522.

Neale DB, Ingvarsson PK. 2008. Population, quantitative and comparative genomics of adaptation in forest trees. Current Opinion in Plant Biology 11(2): 149-155.

Neale DB, Kremer A. 2011. Forest tree genomics: Growing resources and applications. Nature Reviews Genetics 12(2): 111-122.

Oikawa A, Joshi HJ, Rennie EA, Ebert B, Manisseri C, Heazlewood JL, Scheller HV. 2010. An integrative approach to the identification of Arabidopsis and rice genes involved in xylan and secondary wall development. PLOS ONE 5(11).

Pagant S, Bichet A, Sugimoto K, Lerouxel O, Desprez T, McCann M, Lerouge P, Vernhettes S, Höfte H. 2002. Kobitol encodes a novel plasma membrane protein necessary for normal synthesis of cellulose during cell expansion in Arabidopsis. Plant Cell 14(9): 2001-2013.

Paredez AR, Somerville CR, Ehrhardt DW. 2006. Visualization of cellulose synthase demonstrates functional association with microtubules. Science 312(5779): 1491-1495.

Pastuglia M, Bouchez D. 2007. Molecular encounters at microtubule ends in the plant cell cortex. Current Opinion in Plant Biology 10(6): 557-563. 
Plaisier CL, Horvath S, Huertas-Vazquez A, Cruz-Bautista I, Herrera MF, Tusie-Luna T, AguilarSalinas C, Pajukanta P. 2009. A systems genetics approach implicates USF1, FADS3, and other causal candidate genes for familial combined hyperlipidemia. PLoS Genetics 5(9).

Ralph J, Lundquist K, Brunow G, Lu F, Kim H, Schatz PF, Marita JM, Hatfield RD, Ralph SA, Christensen JH, Boerjan W. 2004. Lignins: Natural polymers from oxidative coupling of 4hydroxyphenyl- propanoids. Phytochemistry Reviews 3(1-2): 29-60.

Richard TL. 2010. Challenges in scaling up biofuels infrastructure. Science 329(5993): 793-796.

Robinson AR, Mansfield SD. 2011. Metabolomics in Poplar. In C. P. Joshi, S. Difazio and K. Chittaranjan (Eds). Genetics, Genomics and Breeding of Poplar CRC Press, Science Publishers, Inc., New Hampshire; Edenbridge Ltd., British Isles. Pp. 166-192.

Romanoski CE, Lee S, Kim MJ, Ingram-Drake L, Plaisier CL, Yordanova R, Tilford C, Guan B, He A, Gargalovic PS, Kirchgessner TG, Berliner JA, Lusis AJ. 2010. Systems genetics analysis of gene-by-environment interactions in human cells. American Journal of Human Genetics 86(3): 399-410.

Rudolph U. 1987. Occurrence of rosettes in the ER membrane of young Funaria hygrometrica protonemata. Naturwissenschaften 74(9): 439.

Saxena IM, Brown Jr RM. 2005. Cellulose biosynthesis: Current views and evolving concepts. Annals of Botany 96(1): 9-21.

Scheller HV, Ulvskov P 2010. Hemicelluloses. In. Annual Review of Plant Biology. 263-289.

Schrader J, Nilsson J, Mellerowicz E, Berglund A, Nilsson P, Hertzberg M, Sandberg G. 2004. A high-resolution transcript profile across the wood-forming meristem of poplar identifies potential regulators of cambial stem cell identity. Plant Cell 16(9): 2278-2292.

Sedbrook JC, Ehrhardt DW, Fisher SE, Scheible WR, Somerville CR. 2004. The Arabidopsis SKU6/SPIRAL1 gene encodes a plus end-localized microtubule-interacting protein involved in directional cell expansion. Plant Cell 16(6): 1506-1520.

Sederoff R, Myburg A, Kirst M 2009. Genomics, domestication, and evolution of forest trees.In. 303317.

Séguin A. 2011. How could forest trees play an important role as feedstock for bioenergy production? Current Opinion in Environmental Sustainability 3(1-2): 90-94.

Seifert GJ, Roberts K 2007. The biology of arabinogalactan proteins.In. Annual Review of Plant Biology. 137-161.

Sharma N, Bryant J, Wloga D, Donaldson R, Davis RC, Jerka-Dziadosz M, Gaertig J. 2007. Katanin regulates dynamics of microtubules and biogenesis of motile cilia. Journal of Cell Biology 178(6): 1065-1079.

Somerville C. 2006. Cellulose synthesis in higher plants. Annu Rev Cell Dev Biol 22: 53-78.

Somerville C, Youngs H, Taylor C, Davis SC, Long SP. 2010. Feedstocks for lignocellulosic biofuels. Science 329(5993): 790-792.

Stoppin-Mellet V, Gaillard J, Vantard M. 2006. Katanin's severing activity favors bundling of cortical microtubules in plants. Plant Journal 46(6): 1009-1017.

Strauss SH, Tan H, Boerjan W, Sedjo R. 2009. Strangled at birth? Forest biotech and the Convention on Biological Diversity. Nature Biotechnology 27(6): 519-527.

Studer MH, De Martini JD, Davis MF, Sykes RW, Davison B, Keller M, Tuskan GA, Wyman CE.

2011. Lignin content in natural Populus variants affects sugar release. Proceedings of the

National Academy of Sciences 108: 6300-6305.

Szymanski DB. 2009. Plant cells taking shape: new insights into cytoplasmic control. Current Opinion in Plant Biology 12(6): 735-744.

Taylor NG. 2008. Cellulose biosynthesis and deposition in higher plants. New Phytologist 178(2): 239-252.

Thumma BR, Matheson BA, Zhang D, Meeske C, Meder R, Downes GM, Southerton SG. 2009. Identification of a cis-acting regulatory polymorphism in a eucalypt COBRA-like gene affecting cellulose content. Genetics 183(3): 1153-1164.

Thumma BR, Nolan MF, Evans R, Moran GF. 2005a. Polymorphisms in cinnamoyl CoA reductase (CCR) are associated with variation in microfibril angle in Eucalyptus spp. Genetics 171(3): 1257-1265. 
Tuskan GA, DiFazio S, Jansson S, Bohlmann J, Grigoriev I, Hellsten U, Putnam M, Ralph S, Rombauts S, Salamov A, Schein J, Sterck L, Aerts A, Bhalerao RR, Bhalerao RP, Blaudez D, Boerjan W, Brun A, Brunner A, Busov V, Campbell M, Carlson J, Chalot M, Chapman J, Chen GL, Cooper D, Coutinho PM, Couturier J, Covert S, Cronk Q, Cunningham R, Davis J, Degroeve S, Dŕjardin A, DePamphilis C, Detter J, Dirks B, Dubchak I, Duplessis S, Ehlting J, Ellis B, Gendler K, Goodstein D, Gribskov M, Grimwood J, Groover A, Gunter L, Hamberger B, Heinze B, Helariutta Y, Henrissat B, Holligan D, Holt R, Huang W, IslamFaridi N, Jones S, Jones-Rhoades M, Jorgensen R, Joshi C, Kangasjärvi J, Karlsson J, Kelleher C, Kirkpatrick R, Kirst M, Kohler A, Kalluri U, Larimer F, Leebens-Mack J, Leplé JC, Locascio P, Lou Y, Lucas S, Martin F, Montanini B, Napoli C, Nelson DR, Nelson C, Nieminen K, Nilsson O, Pereda V, Peter G, Philippe R, Pilate G, Poliakov A, Razumovskaya J, Richardson P, Rinaldi C, Ritland K, Rouzé P, Ryaboy D, Schmutz J, Schrader J, Segerman B, Shin H, Siddiqui A, Sterky F, Terry A, Tsai CJ, Uberbacher E, Unneberg P, Vahala J, Wall K, Wessler S, Yang G, Yin T, Douglas C, Marra M, Sandberg G, Van De Peer Y, Rokhsar D. 2006. The genome of black cottonwood, Populus trichocarpa (Torr. \& Gray). Science 313(5793): 1596-1604.

Vanholme R, Morreel K, Ralph J, Boerjan W. 2008. Lignin engineering. Current Opinion in Plant Biology 11(3): 278-285.

Wegrzyn JL, Eckert AJ, Choi M, Lee JM, Stanton BJ, Sykes R, Davis MF, Tsai CJ, Neale DB. 2010. Association genetics of traits controlling lignin and cellulose biosynthesis in black cottonwood (Populus trichocarpa, Salicaceae) secondary xylem. New Phytologist 188(2): 515532.

Wightman R, Turner SR. 2008. The roles of the cytoskeleton during cellulose deposition at the secondary cell wall. Plant Journal 54(5): 794-805.

Wu AM, Hörnblad E, Voxeur A, Gerber L, Rihouey C, Lerouge P, Marchant A. 2010. Analysis of the Arabidopsis IRX9/IRX9-L and IRXI4/IRXI4-L pairs of glycosyltransferase genes reveals critical contributions to biosynthesis of the hemicellulose glucuronoxylan. Plant Physiology 153(2): 542-554.

Wu AM, Rihouey C, Seveno M, Hörnblad E, Singh SK, Matsunaga T, Ishii T, Lerouge P, Marchant A. 2009. The Arabidopsis IRX10 and IRX10-LIKE glycosyltransferases are critical for glucuronoxylan biosynthesis during secondary cell wall formation. Plant Journal 57(4): 718731.

Xie L, Yang C, Wang X. 2011. Brassinosteroids can regulate cellulose biosynthesis by controlling the expression of CESA genes in Arabidopsis. Journal of Experimental Botany 62(13): 44954506.

Yamaguchi M, Goué N, Igarashi H, Ohtani M, Nakano Y, Mortimer JC, Nishikubo N, Kubo M, Katayama Y, Kakegawa K, Dupree P, Demura T. 2010. VASCULAR-RELATED NACDOMAIN6 and VASCULAR-RELATED NAC-DOMAIN7 effectively induce transdifferentiation into xylem vessel elements under control of an induction system. Plant Physiology 153(3): 906-914.

York WS, O'Neill MA. 2008. Biochemical control of xylan biosynthesis - which end is up? Current Opinion in Plant Biology 11(3): 258-265.

Zhang Y, Brown G, Whetten R, Loopstra CA, Neale D, Kieliszewski MJ, Sederoff RR. 2003. An arabinogalactan protein associated with secondary cell wall formation in differentiating xylem of loblolly pine. Plant Molecular Biology 52(1): 91-102.

Zhong R, Burk DH, Morrison Iii WH, Ye ZH. 2002. A kinesin-like protein is essential for oriented deposition of cellulose microfibrils and cell wall strength. Plant Cell 14(12): 3101-3117.

Zhong R, Demura T, Ye ZH. 2006. SND1, a NAC domain transcription factor, is a key regulator of secondary wall synthesis in fibers of Arabidopsis. Plant Cell 18(11): 3158-3170.

Zhong R, Lee C, Ye ZH. 2010. Functional characterization of poplar wood-associated NAC domain transcription factors. Plant Physiology 152(2): 1044-1055.

Zhong R, Lee C, Zhou J, McCarthy RL, Ye ZH. 2008. A battery of transcription factors involved in the regulation of secondary cell wall biosynthesis in Arabidopsis. Plant Cell 20(10): 27632782 . 
Zhong R, Richardson EA, Ye ZH. 2007. Two NAC domain transcription factors, SND1 and NST1, function redundantly in regulation of secondary wall synthesis in fibers of Arabidopsis. Planta 225(6): 1603-1611.

Zhong R, Ye ZH. 2010. The poplar PtrWNDs are transcriptional activators of secondary cell wall biosynthesis. Plant Signaling and Behavior 5(4): 469-472.

Zhong R, McCarthy RL, Lee C, Ye Z-H. 2011. Dissection of the Transcriptional Program Regulating Secondary Wall Biosynthesis during Wood Formation in Poplar. Plant Physiology doi: $10.1104 /$ pp. 111.181354

\section{Figure legends}

Figure 1. Examples of the diversity of currently produced, high-value derivatives of woodderived cellulose. The structure of the repeating unit of cellulose - cellobiose - is shown in the middle, with a "head-to-tail" arrangement of two glucose molecules bound via beta $1-4$ linkage. The side-chain substitution of the hydroxyl groups from $\mathrm{C}_{2}, \mathrm{C}_{3}$ and/or $\mathrm{C}_{6}$ (highlighted in red) result in the production of a variety of unique physicochemical derivatives, all of which comprise diverse industrial and commercial products (top). Pure crystalline cellulose can also be broken up into microcrystalline cellulose (bottom) by chemical disruption of the non-crystalline regions, or alternatively the entire polymer can be separated into nanocellulose crystals.

Figure 2. An integrated view of currently known proteins and some cellular processes involved in cellulose and xylan biosynthesis. Proteins are indicated as coloured circles in the cell areas they are associated with, and classes of proteins are coloured as indicated by the legend on the bottom left. Note that proximity of proteins in the figure does not imply interaction. Actin (blue beads) and microtubules (red and orange tubes) are also shown. References for the inclusion of specific proteins and full protein names can be found in the text.

Figure 3. Metabolic pathways and processes leading to cellulose and xylan biosynthesis, based on the Kyoto Encyclopedia of Genes and Genomes (KEGG, 
http://www.genome.jp/kegg/), as well as recent literature revealing putative biosynthetic enzymes involved in xylan biosynthesis (Brown et al., 2007; York \& O'Neill, 2008; Brown et al., 2009; Oikawa et al., 2010). Metabolites are represented as circles, and enzymatic processes or known enzymes of interest as boxes. BGL - beta-glucosidase; CESA - cellulose synthase; SPS - sucrose phosphate synthase; SPP - sucrose phosphate phosphatase.

Figure 4. A systems genetics approach to understanding the molecular basis of complex phenotypic traits in forest trees. Left: Systems genetics allows the molecular dissection of polygenic traits by relating phenotypic and genetic variation in experimental populations to measurable component traits (in developing cells, tissues and organs of trees) segregating in the same populations. Right: Conceptual network resulting from integrating the covariation of complex and component traits, revealing novel correlations among genes, expression modules, metabolites and complex wood phenotypes that would not be observed at the level of the individual. 


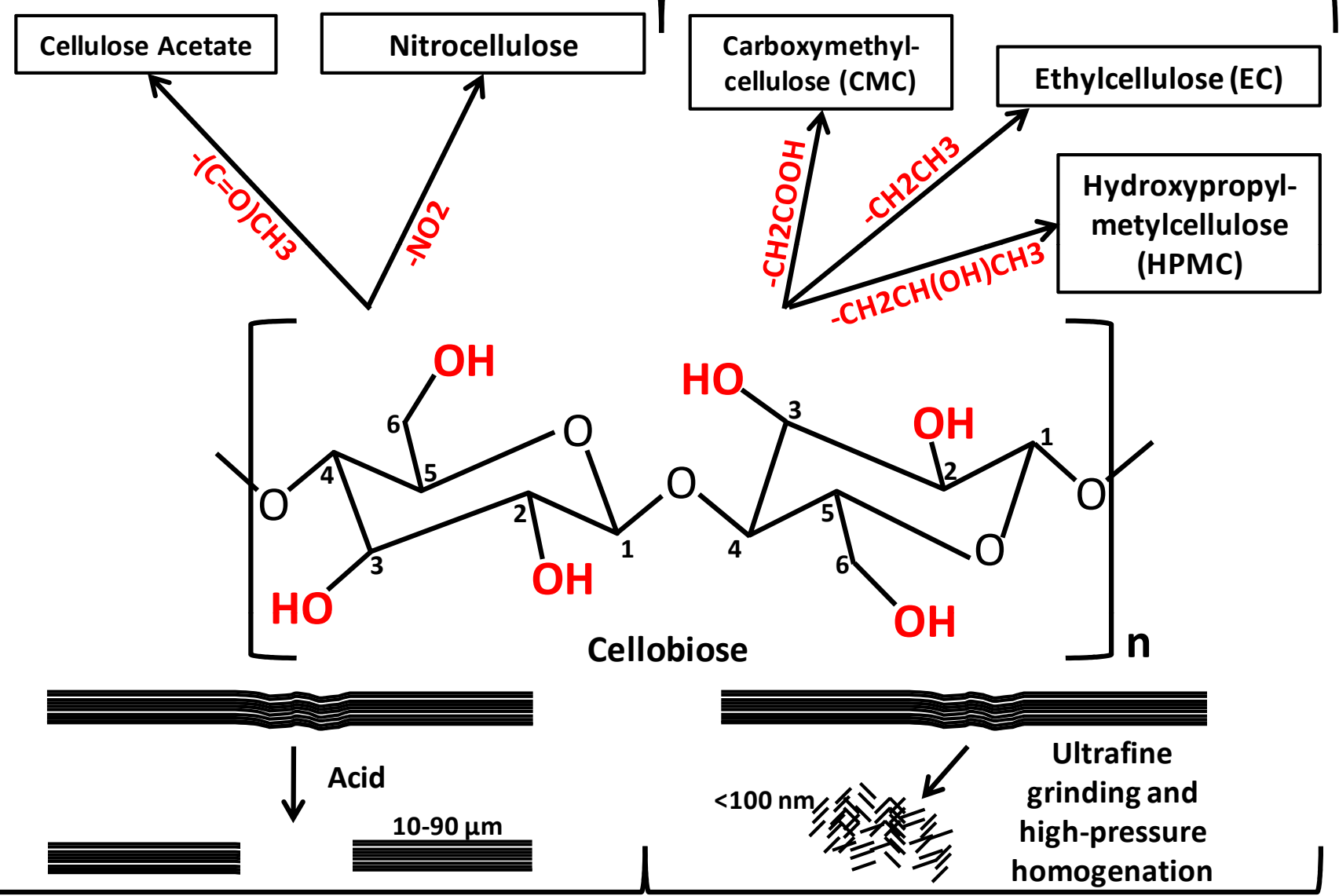


